THE LOGIC OF ECSTASY

CANADIAN MYSTICAL PAINTING 1920-1940 
This page intentionally left blank 


\section{ANN DAVIS}

\section{The Logic of Ecstasy \\ Canadian Mystical Painting 1920-1940}

UNIVERSITY OF TORONTO PRESS

Toronto Buffalo London 
www.utppublishing.com

(C) University of Toronto Press Incorporated 1992

Toronto Buffalo London

Printed in Canada

ISBN 0-8020-5916-3 (cloth)

ISBN 0-8020-6861-8 (paper)

$\infty$

Printed on acid-free paper

\section{Canadian Cataloguing in Publication Data}

Davis, Ann

The logic of ecstasy

Includes bibliographical references and index.

ISBN 0-8020-5916-3 (bound) ISBN 0-8020-6861-8 (pbk.)

1. Painting, Modern - 2oth century - Canada.

2. Painting, Canadian. 3. Mysticism and art Canada. I. Title.

ND245.D38 $1992 \quad 759.11 \quad$ C92-094411-6

This book has been published with the help of a grant from the Canadian Federation for the Humanities, using funds provided by the Social Sciences and Humanities Research Council of Canada. 
To Mum and Dad 
This page intentionally left blank 